\title{
Agriculture Practice and Food Supply in Malaysia for last 50 years
}

\section{Moniruzzaman*1,2 ${ }^{1, \text { Mohammad Imam Hasan Reza**1,2, and Rahima Khatun }}{ }^{2,3}$}

${ }^{1}$ Centre for Environment and Sustainability, Presidency Education, 51 Panchlaish, 4203 Chittagong, Bangladesh; ${ }^{2}$ Southeast Asia Disaster Prevention Research Initiative (SEADPRI), Institute for Environment and Development (LESTARI), Universiti KebangsaanMalaysia, 43600 Bangi, Selangor, Malaysia; ${ }^{3}$ Directorate of Secondary and Higher Education, Ministry of Education, Bangladesh.

*Correspondence: Mohammad Imam Hasan Reza (reza@presidency.ac.bd, rezamih@gmail.com); M. Moniruzzaman (monirbge@gmail.com)

ORCID: M. Moniruzzaman (https://orcid.org/0000-0001-6017-0333)

\section{Highlights:}

- Oil palm mono-culture is practicing in Malaysia

- Domestic food supply is import dependent

- Oil palm export has been continuously increased

\section{Abstract:}

Malaysia is a developing country and agro-industries contribute country's economy. However, it is largely unknown the scenarios of agricultural practice and food supply over the years. To understand the fact, this study was designed to explore the agricultural land use changes and domestic food supply for last 50 years in Malaysia. The result showed that oil palm plantation area and yield, both are increased by folds, conforming "oil palm" mono-culture practice. Rice cultivation area remained almost unchanged but the yield increased. However, both area of plantation and yield in case of rubber, coca and coconut were decreased. When, it comes to domestic food supply, in 1973 food grain (Rice, Wheat, Maize) import was lower than domestic 
production. However, the import increased more than 3 times than the domestic production in 2013. Domestic production of vegetables and vegetables import was almost 50:50. Fruits import increased almost 3 times of domestic production, though domestic production was increased. In conclusion, it is understood that Malaysian agriculture economy is standing on "oil palm" wearers domestic food supply is import dependent. It is high time to reshuffle the policy for sustainable development and achieving food sovereignty.

Keywords: agriculture economy, mono-cropping, food import, sustainable agriculture, food security

\section{Introduction:}

Food security, sustainable agriculture and sustainable development are highly discussed terms now a day. Food security means self-sufficiency in food. A country that does not produce enough food needed for its people or do not have the hard currency to import what is missing, would not be food sovereign (Pinstrup-Andersen, 2009). Practicing sustainable agriculture and sustainable development is important to gain long term food security (Farooq et al., 2019). Sustainable agriculture practice is an ecosystem based farming practice that ensures food production while protecting environment, public health, human communities and animal welfare (Spiertz, 2009). Similarly sustainable development is the balance development considering economic growth, environment degradation and social community (Helbing and Seele, 2017).

Malaysia is a country of increasing population. The population will be increased by 41.5 million by $2040^{1}$. Malaysia is blessed with fertile lands, regular rainfall, adequate sunlight and humid climate that are favorable for its agriculture. Around $20 \%$ (78390 sq. Km) of total land

1

(https://www.dosm.gov.my/v1/index.php?r=column/pdfPrev\&id=Y3kwU2tSNVFDOWp1YmtZY $\underline{\text { nhUeVBEdz09) }}$ 
occupied as agriculture land. Commercial crops (oil palm, rubber and coca) occupied $75 \%$ of total agriculture land. Whereas paddy, fruits, vegetables and coconut covers $16 \%$ of agriculture $\operatorname{land}^{2}$. Oil palm, rubber and coca are three main commercial crops. Oil palm is high yielding and less caring crop. However, this crop is believed as an enemy for environment and society. Deforestation, biodiversity loss, pollution, greenhouse gas emission, social conflict are the major concern regarding oil palm plantation (Khatun et al., 2017). Moreover, mono-cropping is a threat for environment as well as economy (Zhou et al., 2017, Berg, 2002, Lal, 1997, Marais et al., 2012, Altieri, 2009). Rice and coconut are other largely growing crops. In addition to these products, Malaysian farmers produce a number of fruits (bananas, durian, pineapples, rambutan etc.) and vegetables for the domestic market.

Rice is staple food in Malaysia (Ishii et al., 2004). People also consume maize and white products. Potato, cabbage, okra, spinach, tomato and other vegetables are commonly seen in supermarket. Whereas, banana, pea, orange, apple, dates, grape citrus fruits other local fruits are consumed. Foods are being imported to meet consumers demand (Firdaus et al., 2020) and the country is not food sovereign (Sulaiman et al., 2021). Expenditure for food is continuously increasing (Ishida et al., 2003, Ayyash and Sek, 2020) also increasing the dependency on import for domestic food supply (Warr et al., 2008). This article is a critical analysis of the scenario of agricultural practice and domestic food supply in Malaysia. The outcomes of this study provide the insights to reshuffle the police for sustainable development and achieving food sovereignty of Malaysia.

Research methodology and Data collection:

\footnotetext{
${ }^{2}$ (https://www.slideshare.net/ranzcdadavao/overview-of-agriculture-sector-in-malaysiapresentation)
} 
The research was designed to critically analysis the agriculture practice, domestic food supply scenarios and agriculture economy of Malaysia. The primary data sources were FAOSTAT (http://www.fao.org/faostat/en/\#home) and Bureau of statistics Malaysia. Country (Malaysia) specific data was extracted between 1974 and 2013. Data on agriculture land use, crop yield, domestic production of major crops, and import of common food crops then export of commercial crops was collected. For the study of agriculture land use change, land use change caused by major crops- oil palm, rubber, coca, rice, fruits and vegetables was considered. As the land sharing for fruits and vegetables is considerably low, thus we combined these two as one groups. To get data on fruits and vegetables items, local supermarkets were searched for available fruits and vegetables items and finally data retrieve from FAOSTAT database according to the selected items. (Vegetables: cabbage, okra, spinach, tomato other vegetables; Fruits: banana, citrus fruits, fresh fruits and other local fruits). To study the yield change pattern during the study period, yield data of major crops (oil palm, rubber, coca and rice) was extracted. Every 10 year interval data was considered for analysis.

Domestic food production and food import data at every 10 years interval was extracted based on three major category-grains, vegetables and fruits. Rice, wheat and maize were in the category of grain. Potato, beans, tomato and other vegetables were included in the category of vegetables. Pea, orange, apple, dates, grape and local fruits were in the category of fruits. Oil palm and rubber was two major export crops. Export data of these two crops over the time were extracted. Extracted data was analyzed and plotted using MS excel 2010 package.

\section{Results:}

\section{Land use change due to agriculture:}


The only crop "Oil Palm” plantation has been expanded rigorously between 1974 and 2014. In 1974 there was 329800 hectors of oil palm plantation and it continuously expanded to 4689321 by 2014. By last 50 years oil palm expansion was increased by $1321.86 \%$. The expansion percentage of every 10 years interval was ranged between $50 \%$ to $225 \%$ and the maximum expansion was between 1974 and 1984 (Figure 1). Vegetables and fruits cultivation (cabbage, okra, spinach, tomato other vegetables, banana, citrus fruits, fresh fruits and other local fruits) was increased from 34350 in 1974 to 90171 in 2014 . It was around $162 \%$ increased by last 50 years. However, it was less than $2 \%$ of oil palm plantation in 2014 only. Rice cultivation area was remained almost unchanged (around 700000 hectors) during the period. Rubber, the commercial crop, cultivation was decreased by last 50 years. In 1974 there was 1820000 hectors and in 2014 it was decrease to 1065630 hectors. It was more than $40 \%$ decrease by this time. Coca cultivation (96551 hector) was recorded highest in 1984 that was increase form 1200 hectors in 1974. However, it was decreased to 16102 hectors in 2013 (Figure 1).

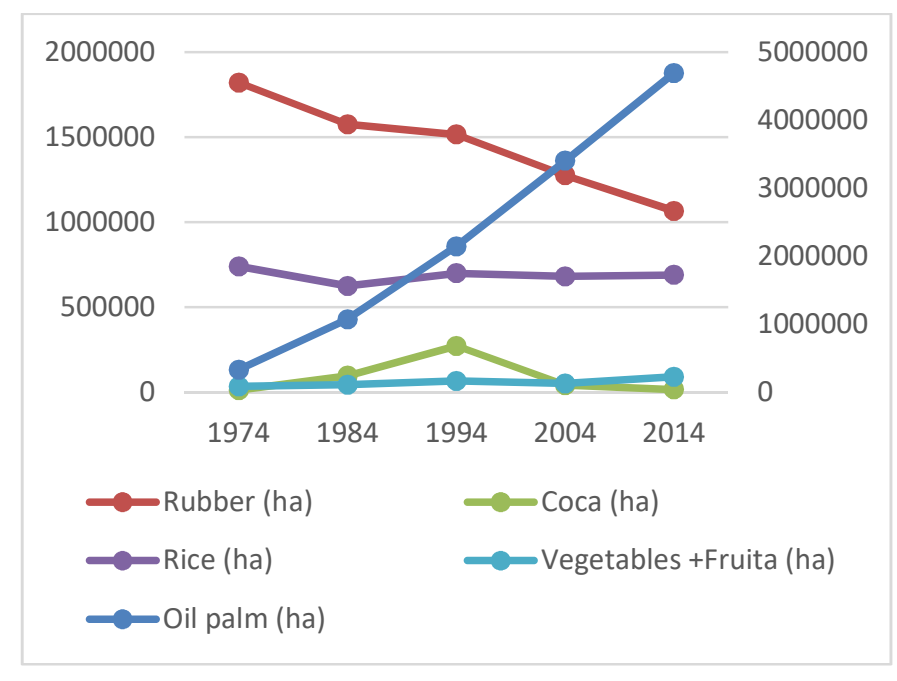

Figure 1: Cultivation area change pattern of major crop in Malaysia between 1974 and 2014.

\section{Yield change pattern of commercial crops:}


During the study period the yield improvement was recorded for "oil palm" and "rice". The greater improvement was found for oil palm. It was $151031 \mathrm{hg} / \mathrm{ha}$ (hectogram/hector) in 1994 that increase to $204863 \mathrm{hg} / \mathrm{ha}$ in 2014 . In total, it was more than $35 \%$ increment from the begging of the study period. Yield for rice cultivation was also increased around $35 \%$ by last 50 years. In 1974 rice yield was found $28311 \mathrm{hg} / \mathrm{ha}$ then it drops to $25187 \mathrm{hg} / \mathrm{ha}$ by following decay after that it gradually increased to $38350 \mathrm{hg} / \mathrm{ha}$ in 2014 . Yield of other two commercial crops (rubber and coca) was declined. In 1974 rubber production was $8378 \mathrm{hg} / \mathrm{ha}$ and in 2014 it was recorded $6274 \mathrm{hg} / \mathrm{ha}$. In total, it was $25 \%$ reduction from the start to end of the study duration. Similarly, coca yield was decreased by $81 \%$ from 1974 to 2014 . Coca production per hector was recorded as 8733 hectograms and slight decrease up to 2004 (8027 hg/ha) then sharply declined to $1655 \mathrm{hg} / \mathrm{ha}$ in 2014 (Figure 2).

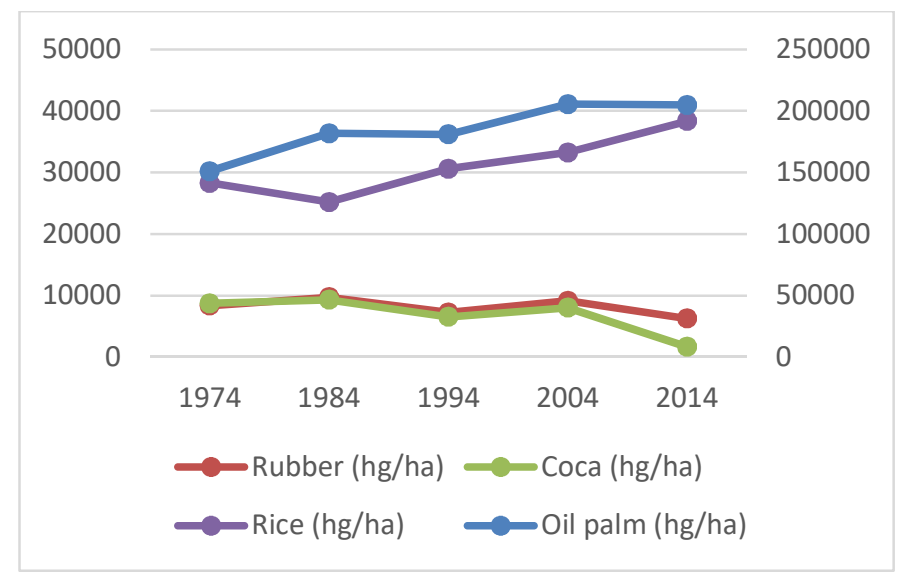

Figure 2: Yield change pattern of major crop in Malaysia between 1974 and 2014.

\section{Food production and import sharing:}

\section{Gains (rice, wheat and maize):}

Both production and import of grains (rice, wheat and maize) were increased with the increase of population. In 1973 total 1337 thousand tonnes of grains was produced. The production was 
declined to 1177 thousand tonnes in 1983 and after that it was increased gradually to 1823 thousand tonnes in 2013. In total, there was $36.35 \%$ increase of domestic production of food grains. On the other hand, food grains import increased drastically. Grains import was reached around 3.5 times more than domestic production. There was around $537 \%$ increased of total grain import during last 50 years. In 1973, grains import was 996 thousand tonnes and it reached to 6344 tonnes in 2013. During the period the population also increased by $156 \%$. In 2013 the population was reached to 29.70 million where it was 11.59 million in 1973 (Figure 3).

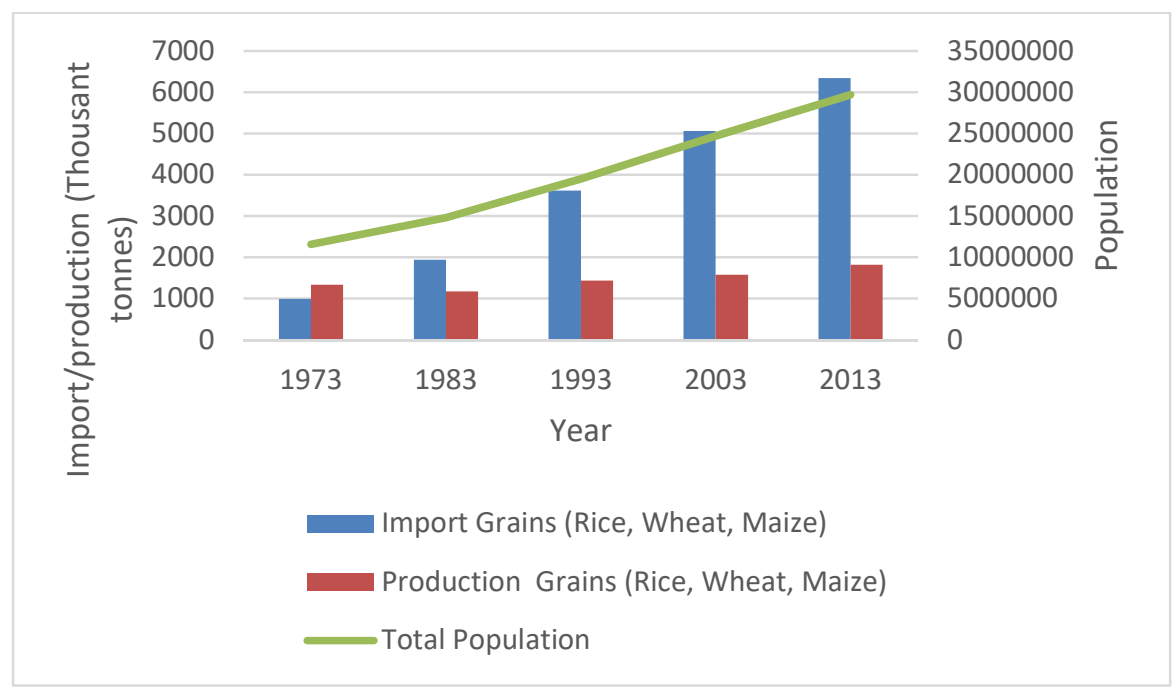

Figure 3: Production and import sharing of grains (Rice, Wheat and Maize) between 1973 and 2013.

Vegetables (potato, beans, tomato and other vegetables):

Like grains, for vegetables both production and import were increased during 1973 to 2013. Vegetables import was increase by $1079.8 \%$ in last 50 years. In 1973, vegetables import was 99 thousand tonnes that was more than $40 \%$ of the domestic production. However in 2013, vegetables import increased more than $83 \%$ of domestic vegetables production. Domestic 
vegetables production increased from 244 thousand tonnes to 1404 thousand tonnes in 2013 (Figure 4).

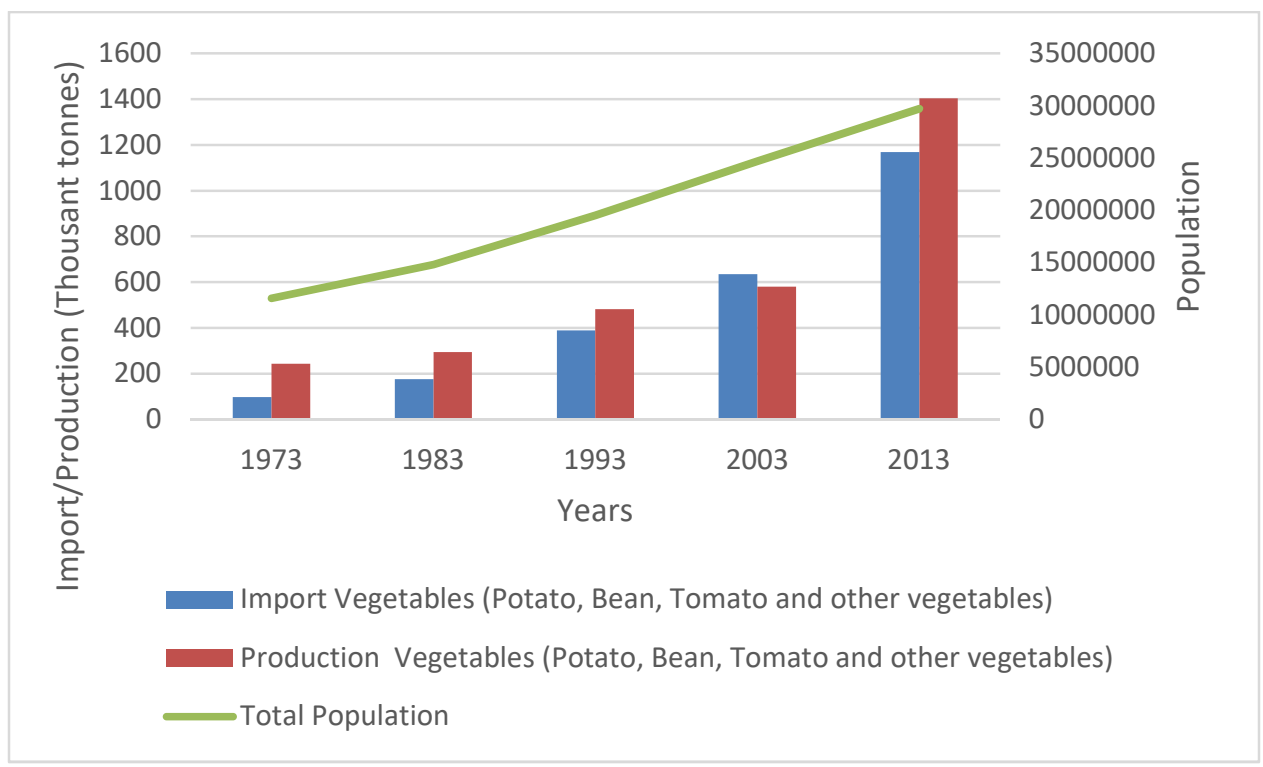

Figure 4: Production and import sharing of vegetables ((Potato, Bean, Tomato and other vegetables) between 1973 and 2013.

Fruits (pea, orange, apple, dates, grape and local fruits):

Both domestic production and import of fruits were increased with time during last 50 years. Form beginning (in 1973) domestic fruit production was almost 4 times than import. However in 2013 fruits import increased around 3 times more than production. There was $1596 \%$ increase of fruits import in 2013 (848 thousand tonnes) in compare to 1973 (50 thousand tonnes). In 1973 domestic fruit production was 194 thousand tonnes. It increased gradually up to 448 thousand tonnes in 2003 then decreased to 303 thousand tonnes by 2013 . Overall there was around $56 \%$ increased of domestic fruits production (Figure 5).

Oil palm export trend: 
Oil palm export was increase by $2328.47 \%$ in 2013 in compare to 1973 . The increment was 41 $\%$ to $294 \%$ by every 10 years interval. The highest percent of increment (294\%) was occurred during 1973 to 1983 and the increment was gradually decreased to $41 \%$ between 2003 and 2013 . In 2013 the oil palm export was reached to 19622 thousand tones where it was only 808 thousand tones in 1973 (Figure 6).

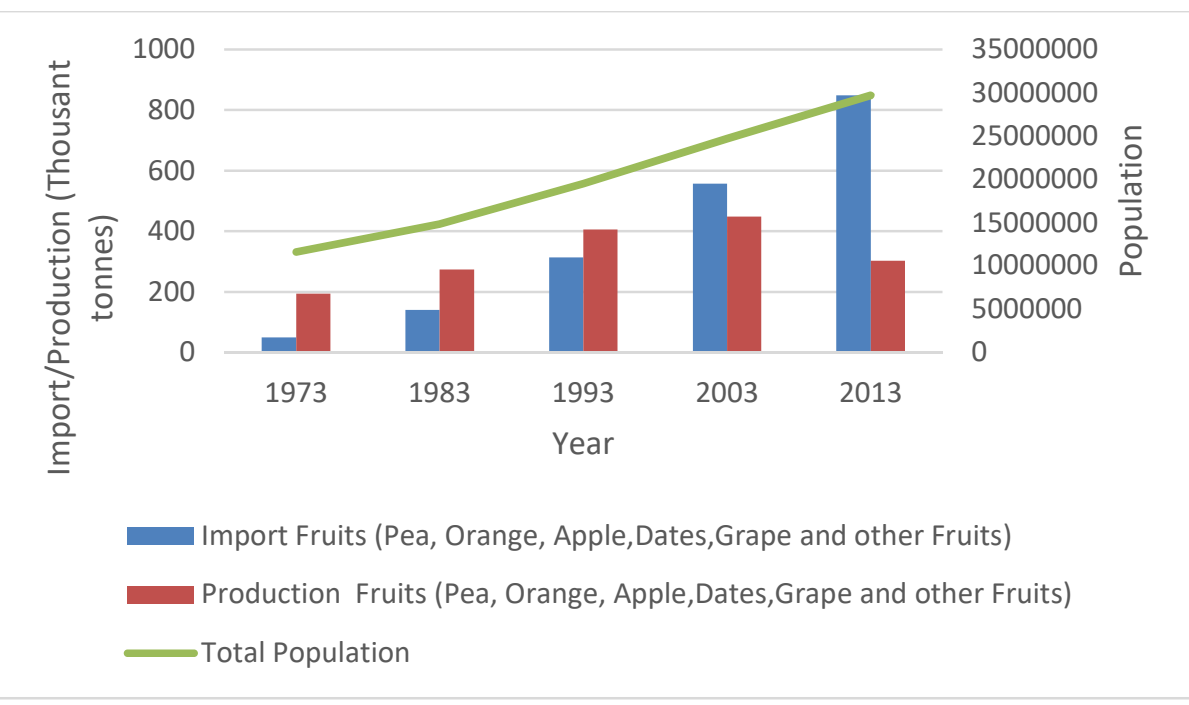

Figure 5: Production and import sharing of fruits (Pea, Orange, Apple, Dates, Grape and other Fruits) between 1973 and 2013.

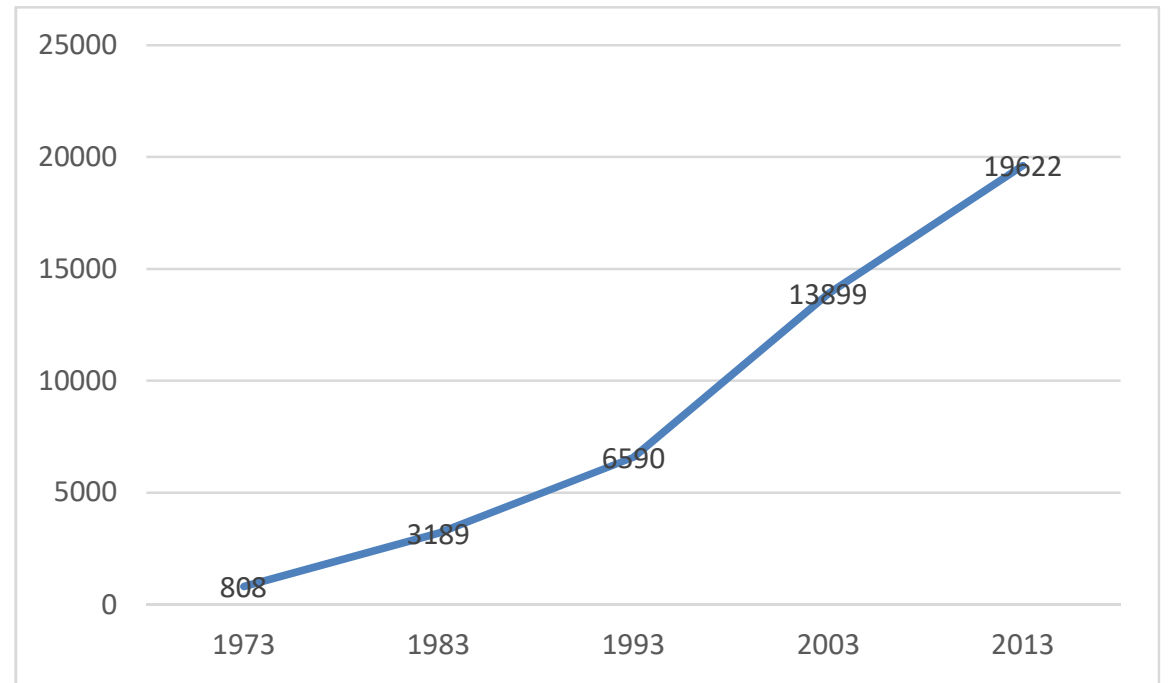


Figure 6: Oil Palm export trend in Malaysia between 1973 and 2013.

\section{Discussion:}

Huge land use change occurred in Malaysia by last 50 years. "Oil palm", the only crop got continuous attention. The plantation was expanded very rapidly to new areas causing deforestation and peat land degradation. Yield of oil palm was increased by 1.5 times since 1973. In case of other crop -rice, the cultivation area was almost same but the yield per hector was increased. For rubber and coca, both area of plantation and yield per hector for rubber and coca were decreased significantly. These scenarios determine the dominance of "Oil Palm" monoculture practice. The sign of mono-cropping is that, a particular crop got more attention, cultivation expanded vigorously and continuously. Mono-cropping can increase expertise on that particular crop thus increase the productivity (Martin et al., 1990). However, it is a serious threat for environment and economy (Zhou et al., 2017, Berg, 2002, Lal, 1997, Marais et al., 2012, Altieri, 2009). Mono-cropping cause biodiversity loss even may cause extinction of less performing varieties of the same species. Degradation of soil health, pollution, creation of superbugs, spreading disease and pests are other major concern of mono-cropping (Dhandapani et al., 2020, Khasanah et al., 2020). Mono-cropping economy is a threat for a country also. Because. invasion of serious disease and pest that might spread very rapidly and it could destroy the crop yield (Haas et al., 2009, Goodwin et al., 1994). On the other hand, appearance of alternative could reduce the use and price that cause economic failure. For example, the price of rubber was dropped in Malaysia due to invention of synthetic rubber (Ratnasingam et al., 2011, Mooibroek and Cornish, 2000, van Beilen and Poirier, 2007, Ali et al., 2021). Moreover, social 
negligence could also reduce the price that might affect country's economy (Polinsky, 1980). On top of that, "Oil palm" itself is also believed "cruel oil" or "green wash" that has serious impact on biodiversity loss and environment pollution (Obidzinski et al., 2012, Meijaard et al., 2020). Acknowledging the importance and environment concern, the oil palm industry is being exploring for sustainable production (Khatun et al., 2017, Fleiss et al., 2020, Rhebergen et al., 2020).

Food import has continuously being increased for last 50 years. It may be because of increased population and increased the ability of people to buy foods. Large sharing of the total consumption of rice is being imported (Ramli et al., 2012, Rajamoorthy and Munusamy, 2015). Vegetables production and import have also increased. It may be because of increased population and health awareness of people to eat vegetables. Consumption of adequate vegetables is important for good health (Van Duyn and Pivonka, 2000). Potato is very common in supermarket but there was no record of potato production. Tomato is being cultivated but the domestic production is very little in compare to import. Both domestic production and import of fruits were increased with times. It may be because of similar reason of vegetables. Apple, orange, grapes are very common fruits found in super market. However, almost all are imported. A good quantity of banana is being produced; however it still needs to import to satisfy local demand. Other local fruits (dowrian, rambutan, papaya, pineapple and mango) were not getting attention to grow as required. GDP contribution to country's economy is holding basically by "oil palm". Oil palm and rubber are the two major commercial crops that are being exported. Oil palm export was increase with time while natural rubber export was declined. Rubber export decreased due to emerge of synthetic rubber and price competition (Ratnasingam et al., 2011, Mooibroek and Cornish, 2000, van Beilen and Poirier, 2007). 


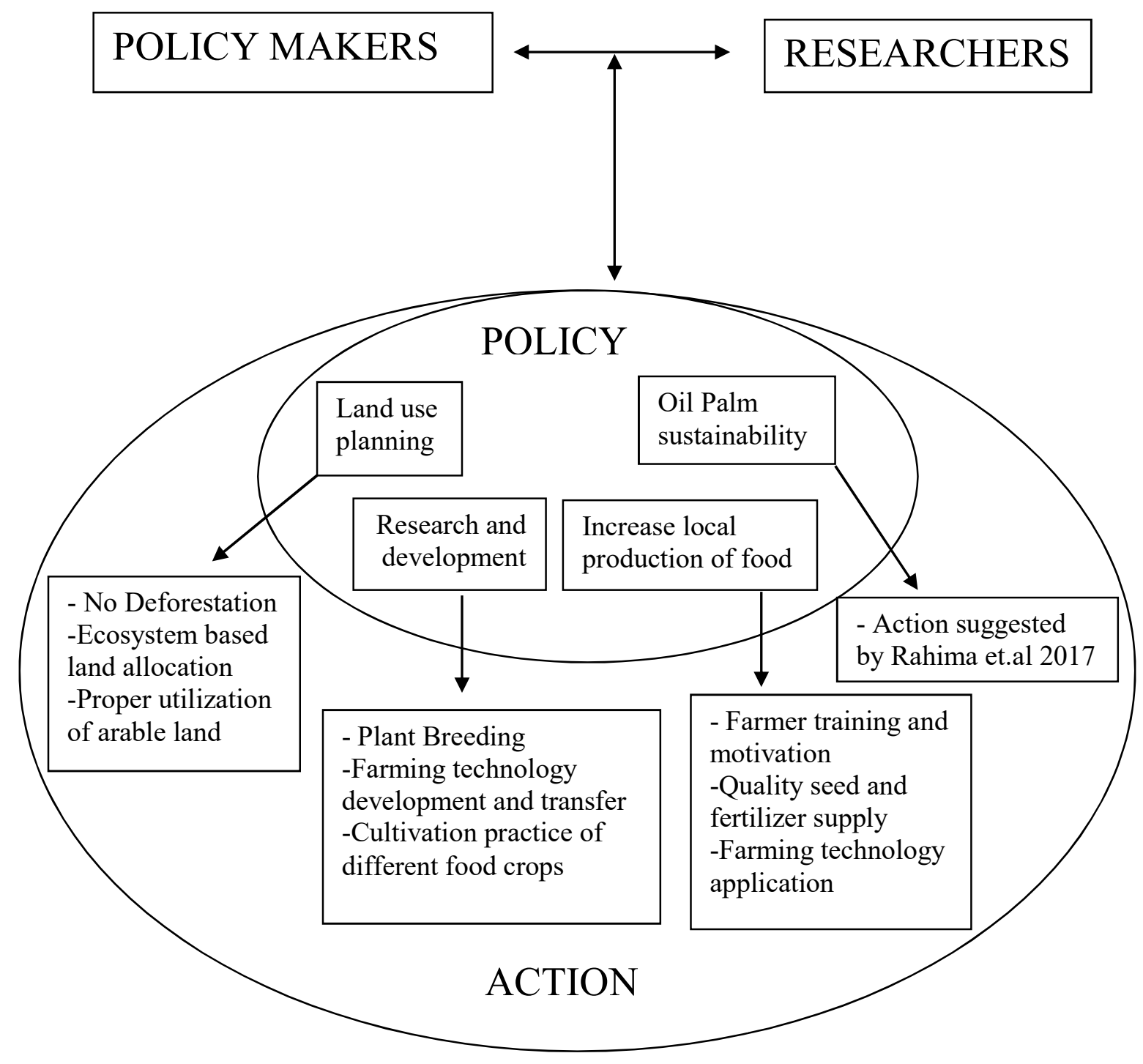

Figure 7: Conceptual framework for sustainable agriculture in case of Malaysia.

\section{Conclusion:}

Malaysian agricultural land use is being changing rapidly and the oil palm monoculture/monocropping is being prevailed since the plantation area rapidly expanded and yield increased. Much 
attention was not paid to other food crops (grain, vegetables and fruit) and food is being imported to mitigate local demand. Domestic food production is not sufficient and food is being imported to mitigate food demand. Malaysian climate is favorable for agriculture practice and it is possible to achieve food sovereignty. The whole process is the cooperative work among policy makers, researchers, agriculture entrepreneurs and farmers (Figure 7). The primary effort is the making and endorsement of policy. Relevant expertise is given priority for picking the most useful plan/policy on a particular field. There might be a number of integrated policies surrounding the agriculture i.e. ecosystem based land use planning, research and development, local food production intensification and sustainability of oil palm industry. Efficient implementation is very important. Monitoring the progress and critically evaluating the feedback could achieve food sovereignty.

\section{Reference:}

ALI, M. F., AKBER, M. A., SMITH, C. \& AZIZ, A. A. 2021. The dynamics of rubber production in Malaysia: Potential impacts, challenges and proposed interventions. Forest Policy and Economics, 127, 102449.

ALTIERI, M. A. 2009. The ecological impacts of large-scale agrofuel monoculture production systems in the Americas. Bulletin of Science, Technology \& Society, 29, 236-244.

AYYASH, M. \& SEK, S. K. 2020. Decomposing Inequality in Household Consumption Expenditure in Malaysia. Economies, 8, 83.

BERG, H. 2002. Rice monoculture and integrated rice-fish farming in the Mekong Delta, Vietnameconomic and ecological considerations. Ecological Economics, 41, 95-107.

DHANDAPANI, S., GIRKIN, N. T., EVERS, S., RITZ, K. \& SJÖGERSTEN, S. 2020. Is Intercropping an Environmentally-Wise Alternative to Established Oil Palm Monoculture in Tropical Peatlands? Frontiers in Forests and Global Change, 3.

FAROOQ, M., REHMAN, A. \& PISANTE, M. 2019. Sustainable Agriculture and Food Security. In: FAROOQ, M. \& PISANTE, M. (eds.) Innovations in Sustainable Agriculture. Springer, Cham.

FIRDAUS, R. R., LEONG TAN, M., RAHMAT, S. R. \& SENEVI GUNARATNE, M. 2020. Paddy, rice and food security in Malaysia: A review of climate change impacts. Cogent Social Sciences, 6, 1818373.

FLEISS, S., WADDELL, E. H., BALA OLA, B., BANIN, L. F., BENEDICK, S., BIN SAILIM, A., CHAPMAN, D. S., JELLING, A., KING, H., MCCLEAN, C. J., YEONG, K. L. \& HILL, J. K. 2020. Conservation set-asides improve carbon storage and support associated plant diversity in certified sustainable oil palm plantations. Biological Conservation, 248, 108631. 
GOODWIN, S. B., COHEN, B. A. \& FRY, W. E. 1994. Panglobal distribution of a single clonal lineage of the Irish potato famine fungus. Proceedings of the National Academy of Sciences, 91, 11591-11595.

HAAS, B. J., KAMOUN, S., ZODY, M. C., JIANG, R. H., HANDSAKER, R. E., CANO, L. M., GRABHERR, M., KODIRA, C. D., RAFFAELE, S. \& TORTO-ALALIBO, T. 2009. Genome sequence and analysis of the Irish potato famine pathogen Phytophthora infestans. Nature, 461, 393.

HELBING, D. \& SEELE, P. 2017. Sustainable development: Turn war rooms into peace rooms. Nature, $549,458$.

ISHIDA, A., LAW, S. H. \& AITA, Y. 2003. Changes in food consumption expenditure in Malaysia. Agribusiness, 19, 61-76.

ISHII, S., MARSHALL, F. M., BELL, J. \& ABDULLAH, A. M. 2004. Impact of ambient air pollution on locally grown rice cultivars (Oryza sativa L.) in Malaysia. Water, air, and soil pollution, 154, 187-201.

KHASANAH, N., VAN NOORDWIJK, M., SLINGERLAND, M., SOFIYUDIN, M., STOMPH, D., MIGEON, A. F. \& HAIRIAH, K. 2020. Oil Palm Agroforestry Can Achieve Economic and Environmental Gains as Indicated by Multifunctional Land Equivalent Ratios. Frontiers in Sustainable Food Systems, 3.

KHATUN, R., REZA, M. I. H., MONIRUZZAMAN, M. \& YAAKOB, Z. 2017. Sustainable oil palm industry: The possibilities. Renewable and Sustainable Energy Reviews, 76, 608-619.

LAL, R. 1997. Long-term tillage and maize monoculture effects on a tropical Alfisol in western Nigeria. I. Crop yield and soil physical properties. Soil and tillage research, 42, 145-160.

MARAIS, A., HARDY, M., BOOYSE, M. \& BOTHA, A. 2012. Effects of monoculture, crop rotation, and soil moisture content on selected soil physicochemical and microbial parameters in wheat fields. Applied and Environmental Soil Science, 2012.

MARTIN, R. C., VOLDENG, H. D. \& SMITH, D. L. 1990. Intercropping corn and soybean for silage in a cooltemperature region: yield, protein and economic effects. Field Crops Research, 23, 295-310.

MEIJAARD, E., BROOKS, T. M., CARLSON, K. M., SLADE, E. M., GARCIA-ULLOA, J., GAVEAU, D. L., LEE, J. S. H., SANTIKA, T., JUFFE-BIGNOLI, D. \& STRUEBIG, M. J. 2020. The environmental impacts of palm oil in context. Nature plants, 6, 1418-1426.

MOOIBROEK, H. \& CORNISH, K. 2000. Alternative sources of natural rubber. Applied microbiology and biotechnology, 53, 355-365.

OBIDZINSKI, K., ANDRIANI, R., KOMARUDIN, H. \& ANDRIANTO, A. 2012. Environmental and social impacts of oil palm plantations and their implications for biofuel production in Indonesia. Ecology and Society, 17.

PINSTRUP-ANDERSEN, P. 2009. Food security: definition and measurement. Food security, 1, 5-7.

POLINSKY, A. M. 1980. Strict liability versus negligence in a market setting. National Bureau of Economic Research Cambridge, Mass., USA.

RAJAMOORTHY, Y. \& MUNUSAMY, S. 2015. Rice industry in Malaysia: challenges, policies and implications. Procedia Economics and Finance, 31, 861-867.

RAMLI, N. N., SHAMSUDIN, M. N., MOHAMED, Z. \& RADAM, A. 2012. The impact of fertilizer subsidy on Malaysia paddy/rice industry using a system dynamics approach. International Journal of Social Science and Humanity, 2, 213.

RATNASINGAM, J., IORAS, F. \& WENMING, L. 2011. Sustainability of the rubberwood sector in Malaysia. Notulae Botanicae Horti Agrobotanici Cluj-Napoca, 39, 305.

RHEBERGEN, T., ZINGORE, S., GILLER, K. E., FRIMPONG, C. A., ACHEAMPONG, K., OHIPENI, F. T., PANYIN, E. K., ZUTAH, V. \& FAIRHURST, T. 2020. Closing yield gaps in oil palm production systems in Ghana through Best Management Practices. European Journal of Agronomy, 115, 126011.

SPIERTZ, J. 2009. Nitrogen, sustainable agriculture and food security: a review. Sustainable Agriculture. Springer.

SULAIMAN, N., YEATMAN, H., RUSSELL, J. \& LAW, L. S. 2021. A Food Insecurity Systematic Review: Experience from Malaysia. Nutrients, 13, 945. 
VAN BEILEN, J. B. \& POIRIER, Y. 2007. Guayule and Russian dandelion as alternative sources of natural rubber. Critical reviews in biotechnology, 27, 217-231.

VAN DUYN, M. A. S. \& PIVONKA, E. 2000. Overview of the health benefits of fruit and vegetable consumption for the dietetics professional: selected literature. Journal of the American Dietetic Association, 100, 1511-1521.

WARR, S., RODRIGUEZ, G. \& PENM, J. 2008. Changing food consumption and imports in Malaysia: Opportunities for Australian agricultural exports, ABARE.

ZHOU, X., LIU, J. \& WU, F. 2017. Soil microbial communities in cucumber monoculture and rotation systems and their feedback effects on cucumber seedling growth. Plant and Soil, 415, 507-520. 